\title{
PENGEMBANGAN MODEL PEMBELAJARAN NUMBERED HEADS TOGETHER UNTUK MENINGKATKAN KETERAMPILAN MENULIS TEKS EKSPLANASI PADA SISWA KELAS XI SMA SWASTA RK DELI MURNI BANDAR BARU
}

\author{
Glaudia Sevani Tarigan ${ }^{1}$, Asnita Hasibuan², Candra Ronitua Gultom ${ }^{3}$ \\ Universitas Katolik Santo Thomas Medan \\ Setia Budi Kp. Tengah Kec. Medan Tuntungan Kota Medan, \\ glaudia.tarigan@gmail.com asnita103hasibuan@gmail.com gultomronny19@ gmail.com
}

\begin{abstract}
Abstrak
Pengembangan model pembelajaran kooperatif tipe NHT ini dikembangkan guna memudahkan guru untuk membantu siswa dalam memahami materi Teks Eksplanasi dan untuk meningkatkan konsentrasi dan hasil belajar siswa. Penelitian dan pengembangan atau Research and Development $(R \& D)$ yang dilakukan mengacu pada prosedural pengembangan Borg dan Gall yang disederhanakan hanya pada batas uji produk terbatas. Pelaksanaan pengembangan secara ringkas dalam eman langkah, dilandasi adanya keterbatasan waktu yang dimiliki oleh peneliti. Keenam langkah tersebut adalah (1) analisis kebutuhan; (2) perencanaan; (3) pengembangan draf; (4) validasi; (5) revisi; (6) uji produk terbatas. Penilaian kelayakan model diperoleh dari hasil validasi oleh ahli materi, guru bahasa Indonesia, dan ahli model pada tahap 2. Aspek yang dinilai oleh ahli materi adalah kualitas materi pembelajaran dan penyajian materi pembelajaran. Sedangkan aspek yang dinilai oleh ahli model adalah aspek desain tampilan, materis dan pemograman. Berdasarkan penilaian akhir ahli materi dan guru bahasa Indonesia, aspek kualitas pembelajaran memiliki rata-rata 4.65 (95.65\%) yang termasuk kedalam kategori sangat baik. Dengan demikian, aspek kualitas pembelajaran model pembelajaran yang dikembangkan dinyatakan layak. Berdasarkan penilaian akhir ahli materi, dan guru bahasa Indonesia, aspek penyajian materi pembelajaran memiliki rata-rata 4.6 (92\%) yang termasuk kedalam kategori sangat baik. Dengan demikian, aspek penyajian materi pembelajaran model pembelajaran yang dikembangkan dinyatakan layak. Berdasarkan penilaian akhir ahli model, aspek desain tampilan memiliki rata-rata 4.1 (82.5\%) yang termasuk dalam kategori sangat baik. Dengan demikian, aspek desain tampilan model pembelajaran yang dikembangkan dinyatakan layak. Berdasarkan penilaian akhir ahli model, aspek pemograman memiliki rata-rata 4.1 (82.5\%) yang termasuk kedalam kategori sangat baik. Dengan demikian, aspek pemograman model pembelajaran yang dikembangkan dinyatakan layak.
\end{abstract}

Kata Kunci: Keterampilan Menulis Teks Eksplanasi, Model Pembelajaran Numbered Heads Together. 


\section{PENDAHULUAN}

Pendidikan

membantu

seseorang untuk mempelajari berbagai hal yang belum diketahuinya untuk mengembangkan atau meningkatkan kemampuan atau potensi-potensinya yang sudah ada dalam dirinya. Dengan pendidikan kita berusaha mengembangkan diri sehingga mampu menghadapi setiap perubahan yang terjadi akibat adanya kemajuan ilmu pengetahuan dan teknologi. Pendidikan adalah wadah untuk dapat menciptakan sumber daya manusia yang bagus atau baik, yang bisa diambil dari pendidikan formal dan non formal.

Dalam Kamus Besar Bahasa Indonesia, pendidikan adalah proses mengubah sikap dan tata laku seseorang atau kelompok orang dalam usaha mendewasakan manusia melalui upaya pengajaran dan latihan, proses, perbuatan, cara mendidik. Dalam pembelajaran bahasa Indonesia keterampilan berbahasa terbagi atas 4 (empat) aspek, yakni keterampilan menyimak, keterampilan berbicara, keterampilan menulis, dan keterampilan membaca. Fokus penelitian penulis adalah salah satu keterampilan yang benar-benar dikuasai oleh setiap manusia. Pesatnya perkembangan ilmu pengetauan dan teknologi menuntut manusia untuk dapat menulis dengan baik dan benar. Menulis merupakan salah satu kompetensi berbahasa yang digunakan dalam berkomunikasi verbal secara tidak langsung untuk menyampaikan suatu informasi atau gagasan. Keterampilan menulis sering sekali menjadi sorotan karena kurangnya motivasi dan penguasaan siswa dalam keterampilan menulis.

Dalam kurikulum 2013 pendidikan sekolah menengah atas (SMA) kelas XI pembelajaran bahasa Indonesia terbagi atas beberapa materi, salah satunya mengenai memproduksi karangan teks eksplanasi. Salah satu Kompetensi Dasar yang harus dikuasai oleh siswa kelas XI dalam kurikulum 2013 adalah memproduksi teks eksplanasi secara lisan maupun tulisan yang terdapat didalam kompetensi 4.4 yang sesuai dengan karakteristik karangan teks eksplanasi dapat dilakukan dalam bentuk keterampilan menulis. Kegiatan memproduksi merupakan bagian dari keterampilan menulis atau menghasilkan tulisan yang menuntut siswa untuk lebih kreatif, inovatif, dan ekspresif dalam mengungkapkan ide atau gagasan.

Teks eksplanasi adalah teks yang menjelaskan tentang proses terjadinya atau terbentuknya suatu fenomena alam atau sosial. Tujuan 
menulis karangan teks eksplanasi di sekolah agar siswa dapat memperkaya pengetahuan mereka mengenai fenomena-fenomena alam maupun sosial. Selain itu juga siswa diharapkan mampu menyusun kerangka teks eksplanasi dan mengembangkan teks eksplanasi ke dalam bentuk tulisan yang utuh dan padu sesuai dengan struktur teks eksplanasi.

Berdasarkan observasi dan wawancara kepada guru bidang studi sekolah bahwa dalam menulis teks eksplanasi masih banyak siswa yang kurang mampu. Disini penulis akan memahami pemahaman siswa dalam membuat karangan teks eksplanasi berdasarkan setiap tulisan siswa, dengan pembelajaran ini sangat berperan penting pencapaian kompetensi pemahaman tentang tulisan teks eksplanasi berdasarkan kemampuan siswa dalam menulis. Hal ini dilakukan agar peroses pembelajaran bahasa Indonesia dapat memberikan hasil yang optimal dan penguasaan Bahasa Indonesia siswa menjadi lebih baik, dimana masih banyak kemampuan siswa dalam menulis teks eksplanasi masih sangat rendah. Hal itu didukung dengan guru mata pelajaran juga masih menggunakan metode pembelajaran yang konvensional dan kurang tepat.
Guru hanya menggunakan metode ceramah dan tanya jawab saja. Lebih cendrung terjadi pembelajaran satu arah, sehingga dalam proses pembelajaran siswa kurang aktif dan kreatif malah lebih cendrung pasif. Dalam hal ini siswa hanya duduk, mendengar, dan mencatat materi pelajaran. Siswa kurang bekerja sama dengan teman-temannya untuk bertukar pikiran. Proses pembelajaran akan terasa sangat membosankan dan hanya berpusat pada guru.Hambatan lainnya dalam penulisan teks ekplanasi adalah penguasaan kosakata yang masih kurang yang menghambat keberhasilan siswa dalam menulis. Kurangnya penguasaan kosakata menyebabkan siswa sering mengulangulang kata yang sama dalam satu paragraf dan mengalami kesulitan dalam memilih kata yang tepat. Siswa juga sering kesulitan dalam mengekspresikan pikiran atau gagasannya melalui bahasa yang baik dan benar, sehingga orang tersebut mengalami kesulitan dalam menulis. Berdasarkan permasalahan tersebut diperlukan model pembelajaran yang dapat mengatasi permasalahan yang dihadapi oleh guru dan siswa tersebut dalam proses pembelajaran menulis teks eksplanasi. Salah satu model pembelajaran yang dapat digunakan 
adalah model pembelajaran Numbered

Heads Together.

Rendahnya kemampuan

menulis siswa menjadi salah satu alasan mengapa model pembelajaran ini dapat terus dikembangakan, yang dapat meningkatkan motivasi belajar siswa dalam berkemampuan akademik sedang dan kurang. Karena model pembelajaran kooperatif merupakan model pembelajaran dengan menggunakan sistem pengelompokan atau tim kecil, yaitu antara tiga sampai lima siswa yang mempunyai latar belakang, kemampuan akademik, jenis kelamin, ras, suku, dan agama yang berbeda-beda (heterogen). Pembelajaran ini sangat cocok dipadukan dengan pembelajaran teks eksplanasi, selain itu dalam pembelajaran kooperatif ini sistem penilaian dilakukan terhadap kelompok dengan memberikan reward (penghargaan) di akhir pembelajaran. Salah satu solusi yang dapat penulis tawarkan untuk mengatasi permasalahan diatas dan memberikan kesempatan kepada siswa untuk mengembangkan kemampuan berfikirnya yaitu dengan model pembelajaran kooperatif. Pembelajaran kooperatif merupakan strategi belajar dengan sejumlah siswa sebagai anggota kelompok kecil yang tingkat kemampuannya berbeda. Dalam menyelesaikan tugas kelompoknya, setiap siswa anggota kelompok harus saling bekerja sama untuk memahami materi pelajaran. Dalam pembelajaran kooperatif, belajar dikatakan belum selesai jika salah satu teman dalam kelompok belum menguasai bahan pelajaran.

Model Pembelajaran Kooperatif tipe Numbered Heads Together, Pembelajaran kooperatif yang mengutamakan adanya kerjasama antar siswa dalam kelompok untuk mencapai tujuan pembelajaran. Para siswa dibagi ke dalam kelompokkelompok kecil dan diarahkan untuk mempelajari materi pelajaran yang telah ditentukan. Tujuan dibentuknya kelompok kooperatif untuk memberikan kesempatan kepada siswa agar dapat terlibat secara aktif dalam proses berpikir dan kegiatan-kegiatan belajar. Dalam hal ini sebagian besar aktifitas pembelajaran berpusat pada siswa, yakni mempelajari materi pelajaran serta berdiskusi untuk memecahkan masalah.Pelaksanaan model pembelajaran Numberd Heads Tohether (NHT) melibatkan para peserta didik untuk dapat mereview bahan dalam suatu pelajaran dan mengecek atau memeriksa pemahaman mereka mengenai isi pelajaran 
tersebut. Model pembelajaran Numbered Heads Together (NHT) memiliki keunggulan yaitu menumbuhkan rasa percaya diri, tanggung jawab dan menempatkan peserta didik untuk lebih aktif, bersemangat serta melatih peserta didik untuk berfikir ilmiah dalam menyelesaikan masalah pada saat pembelajaran sehingga menumbuhkan suasana kelas yang aktif. Numbered Heads Together (NHT) dalam proses pembelajaran menuntut peserta didik untuk dapat bekerja sama secara aktif dalam penguasaan materi yang diberikan guru. Tidak hanya dalam penguasaan konsep materi tetapi peserta didik juga didorong untuk memiliki kemampuan berinteraksi dan bersosialisasi sehingga mempengaruhi hasil belajar peserta didik. Hasil penelitian menunjukkan bahwa pengembangan model pembelajaran NHT seperti disebutkan di judul penelitian sudah dilakukan revisi secara bertahap karena adanya penelitian dari para ahli, hasilnya adalah berkriteria baik (rata-rata 3.75 dari skor tertinggi 4). Jadi perangkat tersebut valid untuk diimplementasikan. Hasil uji coba lapangan menunjukkan uji ketuntasan dan terjadi perbedaan perstasi antara kelas eksperimen dan kelas kontrol serta diperoleh variabel keaktifan dan keterampilan proses berpengaruh positif terhadap prestasi belajar dengan persamaan regresi dan pengaruhnya sebesar 39\%. Hal tersebut menunjukkan pembelajaran kelas eksperimen mencapai efektif. Jadi validitas model pembelajaran dan efektifitas pembelajaran tercapai.

Atas dasar latar belakang masalah sebagaimana telah diutarakan diatas, maka saya memandang penting dan perlu untuk melakukan penelitian dengan judul "Pengembangan Model Pembelajaran Number Heads Together untuk Meningkatkan Keterampilan Menulis Teks Eksplanasi pada Kelas XI SMA RK Deli Murni Bandar Baru”.

\section{KAJIAN TEORI}

1. Keterampilan Menulis

Keterampilan menulis merupakan salah satu jenis keterampilan bahasa yang harus dikuasai oleh siswa. Keterampilan yang paling sulit dari keempat keterampilan adalah keterampilan menulis (Tarigan, 2008). Keterampilan menulis membutuhkan latihan yang rutin supaya seseorang dapat menulis dengan baik. Keterampilan menulis bukan keterampilan yang alami, tidak seperti keterampilan 
berbicara dan menyimak. Setiap manusia hanya dapat memperoleh dan mengembangkan keterampilan menulis dengan menguasai konsep teoritis tentang menulis. Menulis memiliki banyak fungsi. Seperti yang telah diungkapkan oleh D’Angelo (Tarigan, 2008), pada prinsipnya fungsi utama dari tulisan adalah sebagai alat komunikasi yang tidak langsung. Menulis sangat penting bagi pendidikan karena para pelajar akan terasa mudah dan nyaman dalam berfikir secara kritis. Juga dapat memudahkan kita merasakan dan menikmati hubungan-hubungan, memperdalam daya tangkap atau persepsi, memecahkan masalahmasalah yang dihadapi, dan menyusun urutan bagi pengalaman. Tulisan membantu kita dalam menjelaskan pikiranpikiran kita.

Berdasarkan pendapatpendapat diatas sana, dapat dikemukakan bahwa keterampilan menulis adalah keterampilan untuk menuangkan ide, gagasan, serta perasaan seseorang dalam bentuk bahasa tulis sehingga orang lain yang membaca dapat memahami itu tulisan tersebut dengan baik.

\section{Tujuan Menulis}

Setiap penulis harus mempunyai tujuan yang jelas dari tulisan yang akan ditulisnya. Menurut Suriamiharja (1997), tujuan dari menulis adalah agar tulisan yang dibuat dapat dibaca dan dipahami dengan benar oleh orang lain yang mempunyai kesamaan pengertian terhadap bahasa yang dipergunakan. Sedangkan menurut Suparno dan Mohamad Yunus (2008), tujuan yang ingin dicapai seorang penulis bermacam-macam sebagai berikut;

a. Menjadikan pembaca ikut berpikir dan bernalar.

b. Membuat pembaca tahu tentang hal yang diberikan.

c. Menjadikan pembaca beropini.

d. Menjadikan pembaca mengerti.

e. Membuat pembaca terpersuasi oleh isi karangan.

f. Membuat pembaca senang dengan menghayati nilai-nilai yang dikemukakan seperti nilai kebenaran, nilai agama, nilai pendidikan, nilai sosial, nilai moral, nilai kemanusiaan dan nilai esteyika.

$$
\text { Berdasarkan beberapa }
$$
pendapat tersebut, dapat 
disimpulkan bahwa tujuan menulis adalah agar pembaca mengetahui, mengerti dan memahami nilainilai dalam sebuah tulisan sehinggai pembaca ikut berpikir, berpendapat atau melakukan sesuatu yang berhubungan dengan isi tulisan.

\section{Pengertian Teks Eksplanasi}

Teks eksplanasi adalah teks yang berisi tentang proses 'mengapa' dan 'bagaimana' kejadian-kejadian alam, sosial, ilmu pengetahuan, budaya, dan lainnya dapat terjadi. Suatu kejadian baik kejadian alam maupun kejadian sosial yang terjadi di sekitar kita, selalu memiliki hubungan sebab akibat dan memiliki proses. Suatu kejadian yang terjadi di sekitar kita, tidak hanya untuk diamati dan dirasakan saja, tetapi juga untuk dipelajari. Kita dapat mempelajari kejadian tersebut, misalnya dari segi mengapa dan bagaimana bisa terjadi.

Eksplanasi berasal dari bahasa asing (Inggris) yang berarti tindakan menerangkan atau menjelaskan dan keterangan, pernyataan atau fakta yang menjelaskan (The Contemporary
English-Indonesia Dictionary:

651). Pengertian Teks Eksplanasi (Explanation Teks) adalah sebuah teks yang berisi tentang prosesproses yang berhubungan dengan fenomena-fenomena alam, sosial, ilmu pengetahuan, budaya, dan lainnya. Sedangkan Restuti (2013) mengatakan bahwa pengertian teks ekplanasi adalah teks yang menerangkan atau menjelaskan mengenai proses atau fenomena alam maupun sosial.

Teks ini disusun dengan struktur yang terdiri atas bagaianbagian yang memperlihatkan pernyataan umum (pembukaan), deretan penjelas (isi), dan interpretasi/penutup. Bagian pernyataan umum berisi informasi singkat tentang apa yang dibicarakan. Bagian deretan penjelas berisi urutan uraian atau penjelasan tentang peristiwa yang terjadi. Sementara itu, bagian interpretasi berisi pendapat singkat penulis tentang peristiwa yang terjadi. Bagian ini merupakan penutup teks eksplanasi yang boleh ada atau tidak ada.

\section{Ciri-ciri Teks Eksplanasi}

Teks eksplanasi memiliki 3 (tiga) ciri-ciri yang dapat 


\begin{abstract}
memudahkan kita untuk
membedakan antara teks

eksplanasi dengan teks yang

lainnya, berikut ini adalah

penjelasan ketiga ciri-ciri teks

eksplanasi:
\end{abstract}

1. Strukturnya yang terdiri atas pernyataan-pernyataan umum, berurut dengan sebab (mengapa) dan akibat (bagaimana) serta interpretasi.

2. Memuat dan berisikan tentang informasi atau berita yang berdasarkan dengan fakta, faktual, dan kenyataan.

3. Fakta, faktual, dan kenyataan tersebut memuat dan berisikan dengan informasi atau berita yang sifatnya ilmiah atau dengan dasar keilmuan misalnya sains dan lain sebagainya.

\section{Struktur Teks Eksplanasi}

Teks eksplanasi terdiri dari bagian-bagian seperti di bawah ini:

1. Pernyataan Umum

Bagian pertama teks eksplanasi adalah general statement atau yang disebut juga dengan pernyataan umum. Bagian ini menyampaikan topik atau permasalahan yang akan di bahas pada teks eksplanasi yang berupa gambaran umum mengenai apa dan mengapa suatu fenomena tersebut bisa terjadi. General statement ini harus ditulis semenarik mungkin agar pembaca bisa tertarik untuk membaca isi teks secara keseluruhan.

2. Deretan Penjelas

$$
\text { Bagian ini }
$$
mengandung penjelasanpenjelasan mengenai sebuah topik yang dibahas secara lebih mendalam. Bagian ini ditulis untuk menjawab pertanyaan mengapa, bagaimana dan urutan sebabakibat sebuah fenomena yang terjadi. Bagian ini biasanya ditulis dalam 2 atau 3 paragraf.

3. Penutup

Bagian terakhir dari teks eksplanasi adalah closing yang mengandung intisari dan kesimpulan dari fenomena yang telah dibahas. Di dalam bagian ini juga bisa ditambah saran atau juga tanggapan penulis mengenai fenomena tersebut. 
Kaidah Kebahasaan Teks

Eksplanasi

Dalam sebuah teks eksplanasi terdapat beberapa kaidah kebahasaan diantaranya adalah:

1. Fokus pada hal umum (generic), bukan partisipan manusia

(nonhuman participant), misalnya gempa bumi, banjir, hujan, dan udara.

2. Dimungkinkan menggunakan istilah ilmiah

3. Lebih banyak menggunakan kata kerja material dan relasional (kata kerja aktif)

4. Menggunakan konjungsi waktu dan kausal, misalnya jika, bila, sehingga, sebelum, pertama, dan kemudian.

5. Menggunakan kalimat pasif

6. Eksplanasi ditulis untuk membuat justifikasi bahwa sesuatu yang diterangkan secara kausal itu benar adanya.

\section{Pengertian Pengembangan}

Pengembangan adalah suatu usaha untuk meningkatkan kemampuan teknis, konseptual, dan moral sesuai dengan kebutuhan melalui pendidikan dan latihan. Pengembangan juga suatu proses mendesain pembelajaran secara logis, dan sistematis dalam rangka untuk menetapkan segala sesuatu yang akan dilaksanakan dalam proses kegiatan belajar dengan memperhatikan potensi dan kompetensi peserta didik.

Maka pengembangan pelajaran lebih realistik, bukan sekedar idealisme pendidikan yang sulit diterapkan dalam kehidupan. Pengembangan pembelajaran adalah usaha meningkatkan kualitas proses pembelajaran, baik secara materi maupun metodenya. Secara materis, artinya dari aspek bahan ajar yang disesuaikan dengan perkembangan pengetahuan, sedangkan secara metodologis dan substansinya berkaitan dengan pengembangan strategi pembelajaran, baik secara teoritis maupun praktis. Penelitian pengembangan adalah suatu atau langkah-langkah untuk mengembangkan suatu produk baru atau menyempurnakan produk yang telah ada, yang dapat dipertanggung jawabkan. Tujuan dari penelitian ini yaitu untuk menghasilkan produk baru melalui pengembangan.

$$
\text { Berdasarkan pengertian }
$$
pengembangan yang telah 
diuraikan diatas jadi, yang dimaksud dengan pengembangan adalah suatu proses untuk menjadikan potensi yang ada menjadi sesuatu yang lebih baik dan berguna sedangkan penelitian dan pengembangan adalah suatu proses atau langkah-langkah untuk mengembangkan suatu produk atau menyempurnakan produk yang telah ada menjadi produk yang dapat dipertanggung jawabkan.

\section{Model Pembelajaran Numbered}

\section{Heads Together}

\section{Pengertian Numbered Heads}

\section{Together}

Menurut pendapat dari $\mathrm{La}$ Iru da La Ode Safiun Arifin (2012) NHTadalah bagian dari model pembelajaran kooperatif structural, yang menekankan pada strukturstruktur khusus yang dirancang untuk memenuhi pola intraksi siswa. Pembelajaran kooperatif tipe NHT juga merupakan salah satu tipe kooperatif yang menekankan pada struktur khusus yang dirancang untuk mempengaruhi pola intraksi yang memiliki tujuan meningkatkan penguasaan pengetahuan atau akademik. Tipe ini dikembangkan oleh Kagen (dalam Ibrahim 2000).

Dalam pembelajaran dengan menggunakan Numbered Heads Together adalah model pembelajaran yang melibatkan seluruh siswa dalam pembelajaran, Numbered Heads Together atau kepala bernomor adalah pembelajaran yang membentuk satu kelompok dan setiap anak memiliki nomor (Arianti, dkk 2017).

\section{Langkah-langkah Numbered}

\section{Heads Together}

Langkah-langkah tersebut kemudian dikemukakan oleh Ibrahim (2000) menjadi enam langkah sebagai berikut:

1) Persiapan

Tahap ini guru mempersiapkan rancangan dengan membuat Skenario Pembelajaran (SP), Lembar Kerja Siswa atau Lembar Kerja Kelompok (LKS/LKK) yang sesuai dengan model pembelajaran kooperatif tipe NHT.

2) Pembentukan Kelompok Pembentukan kelompok disesuaikan dengan model pembelajaran kooperatif tipe NHT. Guru 
memberi nomor kepada setiap siswa dalam kelompok dan nama kelompok yang berbeda. Penomoran adalah hal yang utama di dalam NHT, dalam tahap ini guru membagi siswa menjadi beberapa kelompok atau tim yang beranggotakan tiga sampai lima orang dan memberi siswa nomor sehingga setiap siswa dalam tim mempunyai nomor berbeda-beda, sesuai dengan jumlah siswa di dalam kelompok. Kelompok yang dibentuk merupakan percampuran yang ditinjau dari latar belakang sosial, ras, suku, jenis kelamin dan kemampuan belajar. Selain itu, dalam pembentukan kelompok digunakan nilai tes awal (pretest) sebagai dasar dalam menentukan masingmasing kelompok.

3) Tiap kelompok harus memiliki buku paket atau buku panduan

Tiap kelompok harus memiliki buku paket atau buku panduan agar memudahkan siswa dalam menyelesaikan LKS/LKK atau masalah yang diberikan oleh guru.

4) Diskusi masalah

Guru membagi LKK kepada setiap kelompok siswa sebagai bahan yang akan dipelajari. Dalam kerja kelompok setiap siswa berpikir bersama untuk menggambarkan dan meyakinkan bahwa tiap siswa mengetahui jawaban dari pertanyaan yang telah ada dalam LKK atau pertanyaan yang telah diberikan oleh guru. Pertanyaan dapat bervariasi, dari yang bersifat spesifik sampai yang bersifat umum.

5) Memanggil nomor anggota atau pemberian jawaban

Tahap ini, guru menyebut satu nomor dan para siswa dari tiap kelompok dengan nomor yang sama mengangkat tangan dan menyiapkan jawaban kepada siswa yang ada di dalam kelas.

6) Memberi kesimpulan

Guru bersama siswa menyimpulkan jawaban akhir dari semua pertanyaan yang 
berhubungan dengan materi yang disampaikan.

\section{Manfaat dan Kelebihan Numbered Heads Together}

Ada beberapa manfaat pada model pembelajaran kooperatif tipe NHT terhadap hasil belajar siswa yang dikemukakan oleh Lundgren dalam Ibrahim (2008), antara lain (1) Rasa harga diri menjadi lebih tinggi; (2) Memperbaiki kehadiran;

Penerimaan terhadap individu menjadi lebih besar; (4) Perilaku mengganggu menjadi lebih kecil; (5) Konflik antara pribadi berkurang; (6) Pemahaman yang lebih mendalam;

Meningkatkan kebaikan budi, kepekaan dan toleransi; dan (8) Hasil belajar lebih tinggi.

Numbered Heads Together (NHT) dianggap relevan untuk siswa sekolah menengah atas (SMA). NHT menekankan tanggung jawab anggota untuk melakukan tugas mereka berdasarkan jumlah mereka. Siswa harus menunjukkan kemampuan mereka dan menggunakan strategi apa pun untuk mengungkapkan tanggung jawab mereka. Siswa juga dilatih untuk memahami setiap tugas secara komprehensif. Oleh karena itu, tanggung jawab siswa tidak hanya pada proyek individu, tetapi juga sebagai anggota kelompok tertentu. Proses ini mendorong kemampuan siswa untuk memecahkan masalah dan kelengkapan siswa. Selain itu, sebagai bagian dari model pembelajaran kooperatif, NHT menyumbangkan peningkatan keterampilan sosial siswa, ketika mereka berinteraksi dengan guru dan teman sebaya selama pembelajaran (Leasa dan Corebima, 2017).

\section{METODOLOGI PENELITIAN}

Penelitian ini menggunakan metode penelitian dan pengembangan atau Research and Development (R\&D). Penelitian pengembangan ini dilakukan dengan mengacu pada prosedur $\mathrm{R} \& \mathrm{D}$ dari Borg dan Gall (1989) ada 10 langkah pelaksanaan strategi penelitian dan pengembangan, yaitu:

1. Penelitian dan pengumpulan data (Research and information collecting).

2. Perencanaan (Planning).

3. Pengembangan desain/draf produk awal (Develop preliminary from of product).

4. Uji coba lapangan awal (preliminary field testing).

5. Revisi hasil uji coba lapangan awal (Main product revision).

6. Uji coba lapangan (Main field testing).

Penjelasan mengenai langkah penelitian dan pengembangan di atas sebagai berikut: 
1. Penelitian dan pengumpulan data (Research and information collecting)

Langkah awal dalam melakukan studi pendahuluan adalah melakukan penelitian dan pengumpulan data berkaitan dengan model pembelajaran yang diterapkan guru di kelas XI.

2. Perencanaan (Planning)

Setelah melakukan studi pendahuluan, kemudian dilanjutkan dengan merencanakan penelitian. Berdasarkan studi pendahuluan diketahui kebutuhan siswa dalam proses pembelajaran.

3. Pengembangan desain/draf produk awal (Develop preliminary from of product)

Berdasarkan hasil studi pendahuluan dan perencanaan penelitian diatas, peneliti kemudian menyusun rancangan pengembangan Desain pengembangan pembelajaran yang akan digunakan dalam penelitian ini adalah ADDIE. Branch (2009) menggambarkan tahap model NHT yang di dalamnya termasuk perangkat pembelajaran berupa Silabus, RPP, LKS, dan instrumen tes kemampuan menulis teks ekplanasi serta menentukan ahli desain pembelajaran dan ahli materi.

Selanjutnya untuk menilai kualitas pembelajaran diperlukan instrumen kualitas model pembelajaran. Instrumen tersebut meliputi instrumen kevalidasian, kepraktisan dan keefektifan. Sebelum model NHT hasil pengembangan beserta perangkat pembelajaran diterapkan pada uji coba lapangan awal, dilakukan uji coba ahli, yaitu uji coba validasi yang dilakukan oleh dosen ahli desain pembelajaran. Setelah model NHT hasil pengembangan dan perangkat pembelajaran dinyatakan vald, maka dilakukan uji coba lapangan awal. desain pengembangan ADDIE seperti pada gambar 3.1 Menurut Branch (2009) 


\section{Gambar 3.1 ADDIE}

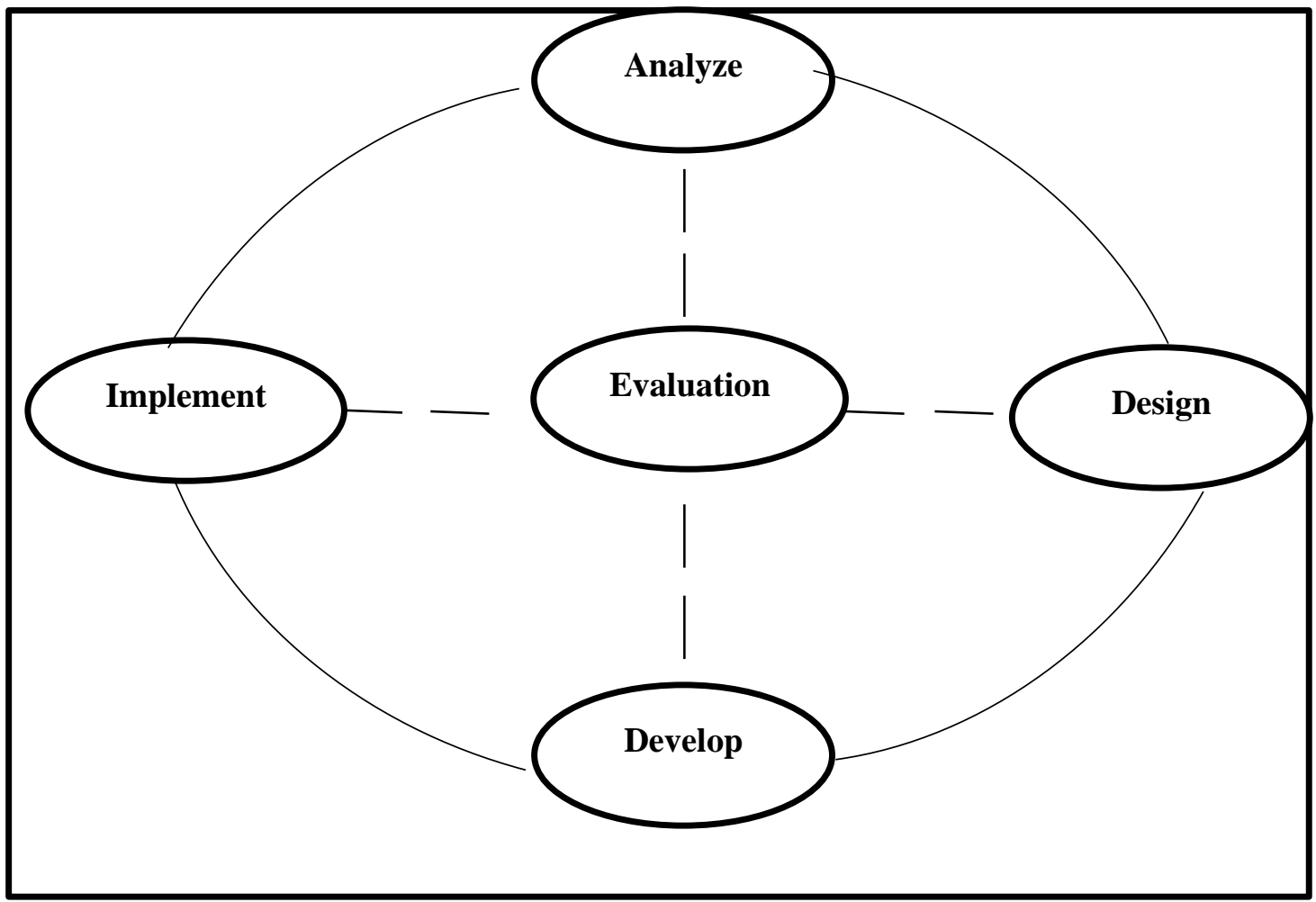

Gambar 3.1 Model ADDIE (Branch 2009)

ADDIE memiliki sebauh prinsip dasar untuk memfasilitasi lingkungan pendidikan dalam mengkonstruk pengetahuan dan kemampuan siswa selama pembelajaran. Sehingga model pembelajaran ADDIE sesuai apabila diterapkan dalam pengembangan pembelajaran. Berikut tahapan ADDIE dalam penelitian ini.

\section{a. Analyze (Analisis)}

Tahap analisis merupakan tahap dimana peneliti menganalisis perlunya pengembangan model pembelajaran dan menganalisis kelayakan serta syarat-syarat pengembangan. Tahap analisis yang dilakukan penulis mencakup tiga hal yaitu analisis kebutuhan, analisis kurikulum, dan analisis karakter peserta didik. Secara garis besar tahapan yang dilakukan sebagai berikut.

1. Analisis Kebutuhan

Analisis kebutuhan dilakukan dengan dahulu menganalisis model pembelajaran yang dilakukan sebagai informasi utama. Model pembelajaran yang dilakukan guru dalam proses pembelajaran bermacam-macam, tetapi guru cendrung menerapkan 
model konvensional dengan metode ceramah dan tanya jawab.

2. Analisis Kurikulum

Analisis kurikulum dilakukan dengan memperhatikan karakteristik kurikulum yang sedang digunakan dalam suatu sekolah. Hal ini dilakukan dengan tujuan agar pengembangan yang dilakukan dapat sesuai tuntutan kurikulum yang berlaku. Kurikulum yang digunakan di SMA RK Deli Murni Bandar Baru adalah kurikulum 2013.

3. Analisis Karakter Peserta Didik

Analisis ini dilakukan untuk melihat sikap peserta didik terhadap pembelajaran Bahasa Indonesia. Hal ini dilakukan agar pengembangan yang dilakukan sesuai dengan karakter siswa. Siswa SMA RK Deli Murni Bandar Baru termasuk siswa yang masih senang bermain dan masih dimasa puber. Jadi ketika guru menerapkan pembelajran kooperatif dalam proses pembelajaran, banyak siswa yang kurang serius dalam pembelajaran. Kegiatan diskusi kelompok sering disalahgunakan siswa untuk bergurau dengan temannya. Permasalahan ini membuat tujuan pembelajaran menjadi tidak tercapai.

\section{b. Design (Perancangan)}

Tahap kedua dari model ADDIE adalah tahap perancangan. Menurut Branch (2008) tujuan dari tahap desain adalah untuk memverifikasi produk yang akan dikembangkan. Pada tahap ini mulai dirancang model pembelajaran yang akan dikembangkan sesuai hasil analisis yang dilakukan sebelumnya. Selanjutnya, tahap perancangan dilakukan dengan menentukan unsurunsur yang diperlukan dalam model pembelajaran.

\section{c. Develpoment (Pengembangan)}

Tahap pengembangan merupakan tahap realisasi produk. Pada tahap ini pengembangan model NHT dilakukan sesuai dengan rancangan. Setelah itu, model NHT hasil pengembangan akan divalidasi oleh dosen ahli desain pembelajaran. Pada proses validasi, validator menggunakan instrumen penelitian untuk menilai langkah-langkah yang terdapat dalam sebuah model pembelajaran.

\section{d. Implementation (Implementasi)}

Implementasi dilakukan secara terbatas pada sekolah yang ditujukan sebagai tempat penelitian, yaitu SMA RK Deli Murni Bandar Baru. Peneliti 
menerapkan model NHT di kelas XI dan mengamati respon siswa dalam proses pembelajaran. Setelah proses pembelajaran selesai, siswa melakukan tes menggunakan instrumen tes kemampuan menulis teks eksplanasi.

\section{e. Evaluation (Evaluasi)}

Pada tahap ini, peneliti melakukan revisi terakhir terhadap model NHT berdasarkan masukan yang didapat dari angket respon guru dan respon siswa. Hal ini bertujuan agar model NHT benar-benar sesuai dan dapat digunakan oleh sekolah yang lebih luas lagi.

4. Uji coba lapangan awal (preliminary field testing)

Model dan perangkat pembelajaran yang telah dinamis dan direvisi kemudian diujicobakan di lapangan awal. Peneliti mengujicobakan model yang telah dikembangkan kepada siswa kelas XI SMA RK Deli Murni Bandar Baru. Model pembelajaran NHT diterapkan di kelas XI A untuk melihat peningkatan kemampuan menulis teks eksplanasi dan respon siswa dalam proses pembelajaran.

5. Revisi hasil uji coba lapangan awal (Main product revision)

Revisi hasil uji coba lapangan awal dilakukan setelah pelaksanaan uji coba dengan mengacu pada hasil analisis angket yang diberikan kepada siswa uji coba dan guru. Selain itu, diamati pula respon siswa dalam proses pembelajaran. Apabila respon siswa dalam proses pembelajaran dinilai positif dan model NHT hasil pengembangan yang memenuhi kriteria praktis, selanjutnya model NHT hasil pengembangan siap untuk diujicobakan di kelas uji coba lapangan untuk menilai efektivitas model tersebut.

6. Uji coba lapangan (Main field testing)

Pada tahap ini uji coba lapangan, desain penelitian yang digunakan adalah pretest-posttestt group design sebagaimana yang dikemukakan Fraenkel dan Wallen (1993). Sebelum melakukan uji coba produk, terlebih dahulu siswa diberikan pretest dengan tujuan untuk mengetahui kemampuan awal siswa mengenai materi yang akan dipelajari. Produk yang berupa pengembangan model NHT selanjutnya diujikan pada siswa dengan cara menerapkannya pada proses pembelajaran. Setelah siswa menerapkan pembelajaran model NHT, siswa diberikan posttest untuk mengetahui efektivitas dari model pembelajaran yang telah dikembangkan yang menitikberatkan pada peningkatan kemampuan menulis teks eksplanasi siswa.

Teknik pengumpulan data pada penelitian dan pengembangan ini dilakukan sebagai berikut.

\section{Angket}

Data mengenai kevalidasian produk yang berupa pengembangan model beserta 
perangkat pembelajaran yang digunakan sebagai pendukung diperoleh melalui lembar validasi. Lembar validasi yang digunakan antara lain lembar penilaian kevalidasian komponen model pembelajaran, RPP, LKS, dan tes kemampuan menulis teks eksplanai. Data mengenai kepraktisan model NHT hasil pengembangan diperoleh dari angket kepraktisan guru untuk mempertimbangkan apakah model tersebut dapat diterapkan dikelas berdasarkan penilaian guru. Selain diberikan kepada guru, angket kepraktisan model NHT pula kepada siswa.

\section{Observasi proses pembelajaran}

Obeservasi proses pembelajaran dilakukan untuk mengamati proses pembelajaran Bahasa Indonesia. Observasi dilakukan dengan cara mengisi lembar pengamatan atau obsevasi proses pembelajaran Bahasa Indonesia pada saat pembelajaran berlangsung. Tujuan dilakukannya observasi adalah untuk mengetahui kebutuhan siswa sebagai acuan dalam mengembangkan model pembelajaran.

\section{Wawancara}

Kajian ini bertujuan untuk memperoleh informasi verbal dan gambaran menyeluruh mengenai suatu proses yang menjadi topik wawancara. Pada penelitian ini, wawancara dilakukan kepada guru. Guru yang diwawancara adalah guru Bahasa Indonesia kelas XI.

4. Tes

Pada penelitian ini diberikan tes kepada peserta didik yaitu tes kemampuan menulis teks eksplanasi untuk mengetahui kemampuan peserta didik dalam menggambar, mengekspresikan Bahasa Indonesia, dan menulis. Jenis tes yang diberikan berupa pretest dan posttest.

\section{HASIL DAN PEMBAHASAN}

\section{Pengembangan Model}

1. Langkah pertama peneliti mempersiapkan rancangan dengan membuat Skenario Pembelajaran, Lembar Kerja Siswa atau Lembar Kerja Kelompok (LKS/LKK) yang sesuai dengan model pembelajaran kooperatif tipe NHT.

2. Langkah kedua peneliti membuat pembentukan kelompok disesuaikan dengan model pembelajaran kooperatif tipe NHT. Guru memberi nomor kepada setiap siswa dalam kelompok dan nama kelompok yang berbeda. Penomoran adalah hal yang utama di dalam NHT, dalam tahap ini guru membagi siswa menjadi beberapa kelompok atau tim yang beranggotakan tiga sampai lima orang dan memberi siswa nomor sehingga setiap siswa dalam tim mempunyai nomor berbeda-beda, 
sesuai dengan jumlah siswa di dalam

kelompok. Kelompok yang dibentuk

merupakan percampuran yang

ditinjau dari latar belakang sosial,

ras, suku, jenis kelamin dan

kemampuan belajar. Selain itu,

dalam pembentukan kelompok

digunakan nilai tes awal (pretest)

sebagai dasar dalam menentukan

masing-masing kelompok.

3. Langkah ketiga peneliti menegaskan tiap kelompok harus memiliki buku paket atau buku panduan agar memudahkan siswa dalam menyelesaikan LKS/LKK atau masalah yang diberikan oleh guru.

4. Langkah keempat peneliti membagi LKK kepada setiap kelompok siswa sebagai bahan yang akan dipelajari. Dalam kerja kelompok setiap siswa berpikir bersama untuk menggambarkan dan meyakinkan bahwa tiap siswa mengetahui jawaban dari pertanyaan yang telah ada dalam LKK atau pertanyaan yang telah diberikan oleh guru. Pertanyaan dapat bervariasi, dari yang bersifat spesifik sampai yang bersifat umum.

5. Langkah kelima adalah pengembangan peneliti yaitu “membantu kinerja siswa" disini peneliti atau guru hadir diantara siswa dan memperhatikan setiap kinerja siswa dengan kelompok yang sudah ditentukan dan telah mempunyai materi mereka masingmasing. Pada langkah kelima ini juga dapat memperkuat hubungan guru dan siswa.

6. Langkah keenam tahap ini, peneliti menyebut satu nomor dan para siswa dari tiap kelompok dengan nomor yang sama mengangkat tangan dan menyiapkan jawaban kepada siswa yang ada di dalam kelas.

7. Langkah ketujuh atau langkah terakhir peneliti bersama siswa menyimpulkan jawaban akhir dari semua pertanyaan yang berhubungan dengan materi yang disampaikan.

\section{Analisis Data Validasi}

Analisis data validasi dilakukan dengan cara mengkonversi data kuantitatif ke data kualitatif pada lembar evaluasi. Tujuan pengubahan tersebut adalah untuk mengetahui kualitas setiap aspek yang telah dinilai. Pengubahan jenis data dilakukan menggunakan skala Likert rentang skor 1-5. Rentang kategori dimulai dari sangat kurang baik sampai pada rentang sangat baik. Selain itu analisis dilakukan terhadap komentar dan saran yang diberikan oleh ahli materi dan ahli model. 
Tabel 4.19 Analisis Data Hasil Validasi Ahli Materi

\begin{tabular}{c|l|l|l|l}
\hline Tahap & \multicolumn{1}{|c|}{ Aspek Yang Dinilai } & Rata-rata & \multicolumn{1}{|c|}{$\%$} & \multicolumn{1}{|c}{ Kategori } \\
\hline \multirow{3}{*}{1} & Kualitas Materi Pembelajaran & 3.9 & $78.9 \%$ & Baik \\
\cline { 2 - 5 } & Penyajian Materi Pembelajaran & 3.7 & $74 \%$ & Baik \\
\cline { 2 - 5 } & Jumlah rata-rata & $\mathbf{3 . 8}$ & $\mathbf{7 6 . 5}$ & Baik \\
\hline \multirow{2}{*}{2} & Kualitas Materi Pembelajaran & 4.6 & $92.6 \%$ & S. Baik \\
\cline { 2 - 5 } & Penyajian Materi Pembelajaran & 4.7 & $94 \%$ & S. Baik \\
\cline { 2 - 5 } & Jumlah rata-rata & $\mathbf{4 . 6 5}$ & $\mathbf{9 3 . 3 \%}$ & S. Baik \\
\hline
\end{tabular}

Tabel 4.20 Analisis Data Hasil Validasi Guru

\begin{tabular}{l|l|c|c|l}
\hline \multicolumn{1}{c|}{ Tahap } & \multicolumn{1}{|c|}{ Aspek Yang Dinilai } & Rata-rata & \% & \multicolumn{1}{|c}{ Kategori } \\
\hline \multirow{3}{*}{1} & Kualitas Materi Pembelajaran & 3.6 & $73.7 \%$ & Baik \\
\cline { 2 - 5 } & Penyajian Materi Pembelajaran & 4.2 & $85 \%$ & S. Baik \\
\cline { 2 - 5 } & Jumlah rata-rata & $\mathbf{3 . 9}$ & $\mathbf{7 9 . 4 \%}$ & Baik \\
\hline \multirow{3}{*}{2} & Kualitas Materi Pembelajaran & 4.7 & $98.7 \%$ & S. Baik \\
\cline { 2 - 5 } & Penyajian Materi Pembelajaran & 4.5 & $90 \%$ & S. Baik \\
\cline { 2 - 5 } & Jumlah rata-rata & $\mathbf{4 . 6}$ & $\mathbf{9 4 . 4 \%}$ & S. Baik \\
\hline
\end{tabular}

Tabel 4.21 Analisis Hasil Validasi Ahli Model

\begin{tabular}{l|l|c|c|l}
\hline \multicolumn{1}{c|}{ Tahap } & \multicolumn{1}{|c|}{ Aspek Yang Dinilai } & Rata-rata & \% & \multicolumn{1}{|c}{ Kategori } \\
\hline \multirow{3}{*}{$\mathbf{1}$} & Desain Tampilan & 3.3 & $66.2 \%$ & Baik \\
\cline { 2 - 5 } & Pemograman & 3.6 & $72.5 \%$ & Baik \\
\cline { 2 - 5 } & Jumlah rata-rata & $\mathbf{3 . 5}$ & $\mathbf{6 9 . 4 \%}$ & Baik \\
\hline \multirow{2}{*}{$\mathbf{2}$} & Desain Tampilan & 4.1 & $82.5 \%$ & S. Baik \\
\cline { 2 - 5 } & Pemograman & 4.1 & $82.5 \%$ & S. Baik \\
\cline { 2 - 5 } & Jumlah rata-rata & $\mathbf{4 . 1}$ & $\mathbf{8 2 . 5 \%}$ & S. Baik \\
\hline
\end{tabular}


Analisis Kelayakan

Analisis kelayakan dilakukan untuk mengetahui tingkat kelayakan dan kategori masing-masing aspek berdasarkan hasil validasi ahli materi dan ahli model. Aspekaspek yang dinilai akan dikategorikan "Layak" jika prosentase dari rata-rata skor yang didapatkan setiap aspek berada dalam kategori Baik (60.1\%-80\%) dan Sangat Baik $(80.1 \%-100 \%)$.
Penilaian kelayakan model diperoleh dari hasil validasi oleh ahli materi, guru bahasa Indonesia, dan ahli model pada tahap 2. Aspek yang dinilai oleh ahli materi adalah kualitas materi pembelajaran dan penyajian materi pembelajaran. Sedangkan aspek yang dinilai oleh ahli model adalah aspek desain tampilan, materis dan pemograman.

Tabel 4.24 Analisis Kelayakan Berdasarkan Validitas Ahli Materi dan Ahli Model

\begin{tabular}{l|l|c|c|l}
\hline $\begin{array}{c}\text { Narasumber } \\
\text { Validasi }\end{array}$ & \multicolumn{1}{|c|}{ Aspek } & Rata-rata & Tingkat Kelayakan & Kategori \\
\hline \multirow{2}{*}{ Ahli Materi } & Kualitas Materi Pembelajaran & 4.6 & $92.6 \%$ & S. Baik \\
\cline { 2 - 5 } & Penyajian Materi Pembelajaran & 4.7 & $94 \%$ & S. Baik \\
\hline \multirow{2}{*}{ Guru } & Kualitas Materi Pembelajaran & 4.7 & $98.7 \%$ & S. Baik \\
\cline { 2 - 5 } & Penyajian Materi Pembelajaran & 4.5 & $90 \%$ & S. Baik \\
\hline Ahli Model & Desain Tampilan & 4.1 & $82.5 \%$ & S. Baik \\
\cline { 2 - 5 } & Pemograman & 4.1 & $82.5 \%$ & S. Baik \\
\hline
\end{tabular}

a. Aspek Matitas Pembelajaran

Analisis aspek kualitas pembelajaran dilakukan untuk mengetahui tingkat kelayakan kualitas pembelajaran dalam model yang dikembangkan. Berdasarkan penilaian akhir ahli materi dan guru bahasa Indonesia, aspek kualitas pembelajaran memiliki rata-rata 4.65 $(95.65 \%)$ yang termasuk kedalam kategori sangat baik. Dengan demikian, aspek kualitas pembelajaran model pembelajaran yang dikembangkan dinyatakan layak.

b. Aspek Penyajian Materi Pembelajaran

Analisis aspek penyajian materi pembelajaran dilakukan untuk mengetahui tingkat kelayakan dalam penyajian materi pembelajaran 
dalam model yang dikembangkan. Berdasarkan penilaian akhir ahli materi, dan guru bahasa Indonesia, aspek penyajian materi pembelajaran memiliki rata-rata 4.6 (92\%) yang termasuk kedalam kategori sangat baik. Dengan demikian, aspek penyajian materi pembelajaran model pembelajaran yang dikembangkan dinyatakan layak.

\section{c. Aspek Desain Tampilan}

Analisis aspek desain tampilan dilakukan untuk mengetahui tingkat kelayakan desain model yang dikembangkan.

Berdasarkan penilaian akhir ahli model, aspek desain tampilan memiliki rata-rata $4.1(82.5 \%)$ yang termasuk dalam kategori sangat baik. Dengan demikian, aspek desain tampilan model pembelajaran yang dikembangkan dinyatakan layak.

\section{d. Aspek Pemograman}

Analisis aspek pemograman dilakukan untuk mengetahui tingkat kelayakan pemograman model yang dikembangkan. Berdasarkan penilaian akhir ahli model, aspek pemograman memiliki rata-rata 4.1 (82.5\%) yang termasuk kedalam kategori sangat baik. Dengan demikian, aspek pemograman model pembelajaran yang dikembangkan dinyatakan layak.

\section{Tahap Revisi Produk}

Tahap revisi produk, peneliti merevisi atau memperbaiki model pembelajaran sesuai dengan hasil para ahli validator maupun setelah uji coba dilakukan. Berikut revisi para ahli validator:

\section{a. Hasil Revisi Ahli Materi}

Berdasarkan validasi tahap 1 pembelajaran menulis teks eksplanasi sudah termasuk kedalam kategori "Baik", namun masih perlu dilakukan revisi. Selain memberikan penilaian, ahli materi juga memberikan saran dam masukan. Berikut ini merupakan saran dan masukan yang diberikan oleh ahli materi.

1. Model harus bersifat saintifik, dalam kurikulum 2013 dikenal dengan istilah 5M yakni mengamati, menanya, mengumpulkan informasi, mengasosiasi, dan mengkomunikasikan.

2. Teks yang telah diterapkan dengan model pembelajaran NHT harus dilengkapi sumber.

3. Model pembelajaran ditambah dengan latihan membuat teks pada kegiatan pembelajaran.

4. Pendukung materi seperti gambar atau ilustrasi harus 
mendorong rasa ingin tahu siswa dan disertakan sumber yang akurat.

Semua data dari penilaian ahli materi akan dijadikan pedoman untuk menyempurnakan komponen buku ajar sebelum diuji cobakan kepada siswa.

\section{b. Hasil Revisi Guru}

Berdasarkan validasi yang
dilakukan oleh guru bahasa
Indonesia, model pembelajaran NHT
dalam pembelajaran menulis teks
eksplanasi dinyatakan layak
digunakan. Berdasarkan validasi
tahap 1 pembelajaran menulis teks
eksplanasi sudah termasuk kedalam
kata baik dan sangat baik, namun
masih perlu dilakukan revisi. Berikut
ini merupakan saran dan masukan
yang diberikan oleh guru bidang
studi.

1. Gunakan contoh yang terdapat di lingkungan sekitar siswa

2. Gunakan warna gambar yang lebih menarik

Berdasarkan tabel 4.3 dan 4.4 di atas, dapat disimpulkan bahwa penilaian yang di isi oleh guru bidang studi masih tetap terdapat perbaikan, terutama pada kejelasan gambar.

\section{c. Hasil Revisi Ahli Model}

Berdasarkan validasi tahap 1 terhadap aspek tampilan dan pemograman, model pembelajaran NHT terhadap kemampuan menulis teks eksplanasi masuk kedalam kategori baik, namun masih perlu melakukan beberapa perbaikan sesuai saran dari ahli model. Berikut komentar dan saran ahli model:

1. Gambar atau ilustrasi yang digunakan haruus jelas.

2. Perhatikan tata letak, jenis huruf dan tampilan teks agar sesuai dengan karakter siswa

3. Teks dan model sudah dapat digunakan di lapangan

Berdasarkan tabel 4.5 dan 4.6 di atas, maka dapat disimpulkan bahwa masih sangat perlu adanya perbaikan penyajian dan tampilan. Sehingga kritik dan saran dari ahli model sangat membantu sebagai penyempurnaan pengembangan model pembelajaran NHT. 


\section{Teknik Analisis Data}

\section{Uji t}

Tabel 4.25 Daftar Nilai Tahap 1 Dan Tahap 2 Siswa Kelas XI

\begin{tabular}{|c|c|c|c|}
\hline No & U Nama Siswa & Tahap 1 & Tahap 2 \\
\hline $\mathrm{n} 1$ & Abtrinisa & 65 & 80 \\
\hline $\mathrm{t} 2$ & Afghanioga & 60 & 85 \\
\hline u 3 & Agnes & 60 & 75 \\
\hline $\mathrm{K}_{4}$ & Andru & 70 & 75 \\
\hline$m^{5}$ & Carolin & 75 & 85 \\
\hline e 6 & Chelysa & 75 & 95 \\
\hline n 8 & Clara Pinem & 70 & 95 \\
\hline $\mathrm{e} 8$ & Clara M. & 70 & 85 \\
\hline $\mathrm{n}_{9}$ & Darwan & 70 & 80 \\
\hline 10 & Desiyana & 75 & 80 \\
\hline $\mathrm{k} 11$ & Ega & 75 & 85 \\
\hline $\mathrm{a} 12$ & Eldu & 70 & 80 \\
\hline $\mathrm{n} 13$ & Filia & 80 & 90 \\
\hline 14 & Gratia & 75 & 90 \\
\hline $\mathrm{u}_{15}$ & Hana & 75 & 80 \\
\hline 16 & Indry & 75 & 86 \\
\hline 17 & Laupiga & 70 & 80 \\
\hline $\mathrm{t} 18$ & Louis & 80 & 95 \\
\hline 19 & Mikolis & 65 & 75 \\
\hline $\mathrm{h}_{20}$ & Putri & 60 & 85 \\
\hline$a_{21}$ & Rachel & 75 & 90 \\
\hline i 22 & Rangga & 60 & 75 \\
\hline 123 & Rika & 60 & 75 \\
\hline 24 & Risiana & 75 & 80 \\
\hline $\mathrm{b}_{25}$ & Sony & 65 & 75 \\
\hline $\mathrm{e}_{26}$ & Tio & 60 & 75 \\
\hline${ }_{\mathrm{a}}^{\mathrm{l}} 27$ & Yunita & 80 & 90 \\
\hline j & Nilai Rata-rata & 70 & 83 \\
\hline $\mathrm{a}$ & Standar Deviasi & 6.79 & 6.70 \\
\hline
\end{tabular}

siswa yang

dikemukakan oleh Sudijono 2008, dengan rumus sebagai berikut:

$\mathrm{t}_{0}=\frac{\mathrm{M}_{1}-\mathrm{M}_{2}}{\mathrm{SE}_{\mathrm{M} 1-\mathrm{M} 2}}$
Untuk menghitung $\mathrm{t}_{0}$ maka terlebih dahulu menghitung standar error perbedaan kedua kelompok dengan rumus sebagai berikut:

$\mathrm{SE}_{\mathrm{M}}=\frac{\mathrm{SD}}{\sqrt{\mathrm{N}-1}}$ 


$$
\begin{aligned}
\mathrm{SE}_{\mathrm{M} 1-\mathrm{M} 2} & =\sqrt{\mathrm{SE}_{\mathrm{M} 1}}+S E_{M 2}^{2} \\
\mathrm{SE}_{\mathrm{M}}= & \frac{\mathrm{SD}}{\sqrt{\mathrm{N}-1}} \\
S E_{M 1} & =\frac{6.70}{\sqrt{27-1}} \\
& =\frac{6.70}{\sqrt{26}} \\
& =\frac{6.70}{5.09} \\
& =1.31 \\
S E_{M 2} & =\frac{6.79}{\sqrt{27-1}} \\
& =\frac{6.79}{\sqrt{26}} \\
& =\frac{6.79}{5.09} \\
& =1.33
\end{aligned}
$$

$$
\begin{aligned}
\mathrm{SE}_{\mathrm{M} 1-\mathrm{M} 2} & ={\sqrt{\mathrm{SE}_{\mathrm{M} 1}}}^{2}+S E_{M 2}^{2} \\
& =\sqrt{1.31}^{2}+1.33^{2} \\
& =1.31+1.76 \\
& =3.07
\end{aligned}
$$$$
t_{0}=\frac{M_{1}-M_{2}}{S E_{M 1-M 2}}
$$$$
=\frac{83-70}{3.07}
$$$$
=\frac{13}{3.07}
$$$$
=4.23
$$

Dengan demikian diperoleh nilai $\mathrm{t}_{0}=4.23$ dan $\mathrm{t}_{\mathrm{t}}=$ 1.70329, sehingga dapat disimpulkan $\mathrm{t}_{0}>\mathrm{t}_{\mathrm{t}}=4.23>$ 1.70329. Berarti $\mathrm{H}_{\mathrm{a}}$ diterima sedangkan $\mathrm{H}_{0}$ ditolak.

\section{Efektivitas Hasil Belajar}

Sehingga diketahui efektivitas hasil belajar dapat menghitung peningkatan hasil belajar dari data pretest dan posttest. Rumus yang digunakan adalah :

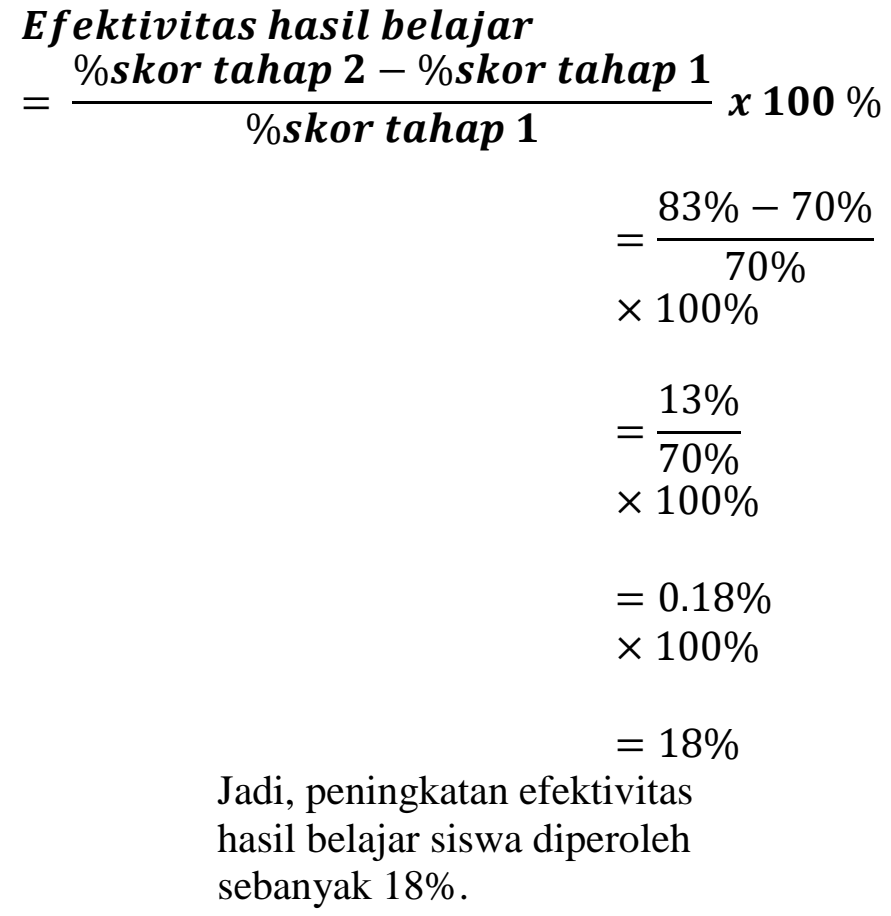

\section{SIMPULAN DAN SARAN}

Penelitian dan pengembangan yang telah dilakukan menghasilkan sebuah produk berupa teks eksplanasi hasil kerja siswa. Produk dikemas dalam bentuk teks, dan dapat menjadi modal mereka di hari kelak. Penelitian dan pengembangan atau Research and Development (R\&D) yang dilakukan mengacu pada prosedural pengembangan Borg dan Gall yang disederhanakan hanya pada batas uji produk terbatas. Alasan pelaksanaan pengembangan secara ada pada langkahlangkah berikut, langkah yang pertama dalam penelitian ini adalah analisis kebutuhan. Analisis kebutuhan diawali dengan melakukan studi pustaka. Studi pustaka yang dilakukan dalam penelitian ini denan cara membaca dan mempelajari Kurikulum 2013 untuk meninjau materi 
yang sesuai dengan media pembelajaran yang akan dikembangkan menggunakan model Numbered Heads Together. Setelah dilakukan analisis kebutuhan, selanjutnya adalah desain produk yang mencakup silabus, RPP, LKS serta instrumen tes kemampuan menulis teks eksplanasi. Langkah kedua dalam penelitian ini adalah peneliti mulai mengembangkan model pelajaran NHT, tahap pertama peneliti melakukan analisis terhadapkebutuhan, analisis kurikulum, analisis peserta didik berdasarkan model pembelajaran NHT. Setelah selesai menganalisis tahap kedua peneliti melakukan perancangan, pada tahap ini mulai dirancang model pembelajaran yang akan dikembangkan sesuai hasil analisis yang dilakukan sebelumnya. Lalu tahap ketiga peneliti melakukan pengembangan model pembelajaran NHT dilakukan dengan rancangan, dan setelah itu model pengembangan akan divalidasi oleh dosen ahli model pembelajaran, validator menggunakan instrumen peneliti untuk menilai langkah-langkah yang terdapat dalam sebuah model pembelajaran. Tahap keempat peneliti melakukan implementasi pada tahap ini peneliti menerapkan model pembelajaran NHT di kelas XI dan mengamati respon siswa dalam proses pembelajaran. Setelah proses pembelajaran selesai siswa melakukan tes menggunakan instrumen tes kemampuan menulis teks eksplanasi. Lalu tahap yang terakhir adalah tahap evaluasi pada tahap ini peneliti melakukan revisi terakhir terhadap model pembelajaran NHT berdasarkan masukan yang didapat dari angket respon guru dan respon siswa.

Penilaian kelayakan model diperoleh dari hasil validasi oleh ahli materi, guru bahasa Indonesia, dan ahli model pada tahap 2. Aspek yang dinilai oleh ahli materi adalah kualitas materi pembelajaran dan penyajian materi pembelajaran. Sedangkan aspek yang dinilai oleh ahli model adalah aspek desain tampilan, materis dan pemograman.

a. Aspek Kualitas Materi Pembelajaran

Analisis aspek kualitas pembelajaran dilakukan untuk mengetahui tingkat kelayakan kualitas pembelajaran dalam model yang dikembangkan. Berdasarkan penilaian akhir ahli materi dan guru bahasa Indonesia, aspek kualitas pembelajaran memiliki rata-rata 4.65 $(95.65 \%)$ yang termasuk kedalam kategori sangat baik. Dengan demikian, aspek kualitas pembelajaran model pembelajaran yang dikembangkan dinyatakan layak.

b. Aspek Penyajian Materi Pembelajaran Analisis aspek penyajian materi pembelajaran dilakukan untuk mengetahui tingkat kelayakan dalam penyajian materi pembelajaran dalam 
model yang dikembangkan.

Berdasarkan penilaian akhir ahli materi, dan guru bahasa Indonesia, aspek penyajian materi pembelajaran memiliki rata-rata $4.6(92 \%)$ yang termasuk kedalam kategori sangat baik. Dengan demikian, aspek penyajian materi pembelajaran model pembelajaran yang dikembangkan dinyatakan layak.

c. Aspek Desain Tampilan

Analisis aspek desain tampilan dilakukan untuk mengetahui tingkat kelayakan desain model yang dikembangkan. Berdasarkan penilaian akhir ahli model, aspek desain tampilan memiliki rata-rata 4.1 $(82.5 \%)$ yang termasuk dalam kategori sangat baik. Dengan demikian, aspek desain tampilan model pembelajaran yang dikembangkan dinyatakan layak.

d. Aspek Pemograman

Analisis aspek pemograman dilakukan untuk mengetahui tingkat kelayakan pemograman model yang dikembangkan. Berdasarkan penilaian akhir ahli model, aspek pemograman memiliki rata-rata $4.1(82.5 \%)$ yang termasuk kedalam kategori sangat baik. Dengan demikian, aspek pemograman model pembelajaran yang dikembangkan dinyatakan layak.

\section{Saran}

Berdasarkan kesimpulan yang didapatkan, berikut adalah saran yang dapat diberikan.

1. Bagi guru, model pembelajaran NHT ini dapat dimanfaatkan sebagai model pembelajaran atau pendukung belajar siswa dalam mempelajari materi pembelajaran Bahasa Indonesia.

2. Bagi pengembang, model ini masih perlu diperbaharui sesuai dengan zaman dan perubahan materi pembelajaran. Pengembang diharapkan dapat memberikan update secara berkala sehingga model pembelajaran ini sesuai dengan perkembangan kurikulum meupun perkembangan siswa.

\section{DAFTAR PUSTAKA}

Borg, W.R dan Gall, M.D. 1989. Educational Research and Introduction. New York: Longman. Branch, R. M. 2009. Instructional DesignThe ADDIE Approach. New York: Springer.

Depdiknas. 2019. Kurikulum 2013 Standar Kompetensi Sekolah Dasar. Jakarta: Depdiknas.

Depdiknas .2019. Permendiknas 2013 Tentang Standar Isi. Jakarta : Depdiknas.

Kosasi, E. 2014. Jenis-jenis Teks dalam Mata Pelajaran Bahasa Indonesia SMA/MA/SMK. Bandung: Yrama Widya. 
Soimin Aris, 2012. Model-model

Pembelajaran inovatis. Kurikulum 2013 Jakarta : Raja Grafindo Persada

Tarigan, Henry Guntur. 2008. Menulis Sebagai Suatu Keterampilan Berbahasa. Bandung: Angkasa. 